\title{
Hawthorne's True Artist in The Marble Faun: The Jewish Miriam?
}

\author{
By Irina Rabinovich ${ }^{*}$
}

\begin{abstract}
The Marble Faun (MF), besides being a travelogue account of Rome, is a story about sin, guilt, suffering and abuse; it is also a tale about love and friendship. It is a story about the relationships between four different individuals united by their mutual love of art. The more interesting and convincing woman of the two female characters in the novel is unquestionably Miriam. Miriam is a rebel, an artist, and a compassionate and redemptive figure. Nevertheless, her art has been almost totally neglected, probably because most critics maintained that Miriam is an allegorical character lacking moral development or growth, whose function in the romance is limited to bringing about the Model's murder and enacting the romance's moral drama. The aim of this paper is to rectify a long and undeserved history of neglect and award Miriam her due status of Hawthorne's sole genuine artist.
\end{abstract}

Keywords: art, Hawthorne's female artists, The Marble Faun

\section{Introduction}

There were many stories about Miriam's origin and previous life, some of which had a very probable air, while others were evidently wild and romantic fables (Hawthorne 1974, p. 22).

Nathaniel Hawthorne's Jewish heroine Miriam, one of the four protagonists of his last completed romance, is a distinctive figure in mid-nineteenth-century American literature, not only because of her Jewishness, but also because of her status as a female artist. Aside from Hawthorne's Hester, the protagonist of his novel The Scarlet Letter and an artist of the needle, no other major figure of a woman artist appears in mid-nineteenth century American literature.

The main questions that have motivated my extensive interest in Miriam's figure are as follows: first, why did Hawthorne, a Christian writer, a New Englander, the son of one of the oldest families in Massachusetts and descendant of devout Puritans, choose a Jewish woman as the main protagonist of his romance? Second, looking at the novel through a cultural lens, I was interested to examine what cultural, historical and societal influences were at play during the process of writing The Marble Faun? Finally, from a feminist point of view, it is worthwhile reflect on what makes a Jewish female artist unique for Hawthorne, so that he would choose to construct such a character for his heroine?

In The Marble Faun (1860), Nathaniel Hawthorne's last published novel, the only artist whose art Hawthorne's narrator seems to admire is a man, the marble sculptor Kenyon, although it might be claimed that Kenyon's hasty departure from

\footnotetext{
"Lecturer and Head, English Language Department, Holon Institute of Technology, Israel.
} 
Rome (the cradle of art) and his failure to complete his masterpiece, the statue of Cleopatra, undermine his status of a "true" artist. The narrator's treatment of the female artists' (Hilda's and Miriam's) art is even more problematic. Hilda is a copyist, fully duty-bound to the "Old Artists"' works of art. She lacks both artistic originality and genuine insight into human nature. The narrator ironically comments that she has "in some instances, even...been enabled to execute what the great Master had conceived in his imagination, but had not so perfectly succeeded in putting upon canvas" (Hawthorne 1974, p. 59). Clearly, Hilda, the dove-like maiden, the innocent "daughter of Puritans," as she calls herself, cannot execute what the Master could, because she has neither the talent, the imagination, nor the sympathy required to produce a real piece of art. However, speaking on behalf of Hilda, and probably on behalf of Hawthorne, the narrator comments:

The mighty Italian Masters...were not human, nor addressed their work to human sympathies, but to a false intellectual taste, which they themselves were the first to create. Well might they call their doings "Art," for they substituted art instead of Nature (Hawthorne 1974, p. 336).

This remark is even more ironic than the narrator's previous comment on Hilda's valueless art. By stating that the Old Masters substituted Nature by tainted Art, the narrator suggests that Hilda's project is a futile one. Instead of creating "Natural," human and empathic art, Hilda actually preserves and promotes the cold, "false intellectual taste" of the Old Masters. At the beginning of the novel the narrator grants Hilda some scant appreciation as an artist, saying that "she bestowed upon it [a painting] all the warmth and richness of a woman's sympathy," (Hawthorne 1974, p. 30) making the reader believe that Hilda's sympathetic female touch might work some magic on reviving the Old Masters' rigid oeuvre. Yet towards the end of the novel, after describing Hilda's heartless treatment of her best friend Miriam, it is clear that Hilda's fake "warmth" can neither make up for the unnaturalness of the Old Masters' art nor for Hilda's future development as an artist. Hilda's rejection of "the Old Masters [who] will not set me [Hilda] free" (Hawthorne 1974, p. 380) comes after her realization that European art is lacking "earnestness and absolute truth" and "moral value" (Hawthorne 1974, p. 381). This rejection reflects her failure to become an artist, similar to Kenyon's failure to complete his statute. At the end of the novel, Kenyon comes to prefer Hilda's love to art, claiming that "imagination and the love of art have both died out of me" (MF 428).

While some critics, such as Kemp (1997, p. 230) and Glazener (1997, pp. 54 55), have briefly referred to Kenyon's art, mainly with the aim of spelling out Hawthorne's artistic credo (since there is almost a unanimous consensus among Hawthorne's critics that Kenyon serves as his creator's mouthpiece), almost no critical attention has been granted to the art of the romance's female protagonists. Hilda's art was dismissed as unoriginal, and thus trivial and irrelevant. Miriam's art has been almost totally neglected, probably because critics such as Bercovitch (1988, p. 633), Brodtkorb (1962, p. 258), and others, asserted that Miriam is an allegorical character devoid of any moral development or growth, whose function in the romance is limited to bringing about the Model's murder and enacting the 
romance's moral drama. Perhaps the mystery that surrounds Miriam's story prevents critics from grasping her immense significance both as a multifaceted individual and as a talented artist.

\section{Miriam's Art}

Contrary to the prevailing critical opinion, Hawthorne's comparative depiction of his artists reveals that Miriam, and not Kenyon, is the most gifted artist in the romance. Only Miriam is able to produce genuine works of art. To Hawthorne, ideal art seems to be art that excludes "the coarse, sensuous and superficial" and includes "the beautiful, good and permanent." True art is human, comforting; its role is to capture moments of grace and emotional engagement with the artist's subjects. Miriam's studio is described according to these principles as a place that captures "the outward type of a poet's haunted imagination, where there are glimpses, sketches, and half-developed hints of beings and objects, grander and more beautiful than we can anywhere find in reality" (Hawthorne, 1974, p. 41). Leo B. Levy correctly maintains that "for Hawthorne, the tradition draws upon the neoclassical categories of sublimity, beauty, grandeur and picturesqueness" (Levy 1970, p. 147).

Miriam asserts that a good artist cannot come to terms with Nature before he/she learns to put him/herself "at odds" with it. When Donatello asks Miriam, while on a visit to her studio, about the reasons for the darkness in the studio, she replies that "we artists purposely exclude sunshine, and all but partial light... because we think it necessary to put ourselves at odd with Nature, before trying to imitate her...we make very pretty pictures sometimes, with our artfully arranged lights and shadows" (Hawthorne 1974, p. 40). This comment not only foreshadows the later description of Miriam's paintings, but has ironic undertones directed towards copyists like Hilda who "imitate" Nature before learning its dark sides, without going through deep processes of contemplation and inner torment. For Miriam, Nature is "Mother Nature." Miriam personifies Nature as female, referring to it as "her" (not its). Before painting natural scenes, Miriam insists on establishing a closer rapport, even intimacy, with her subjects. Hilda, unlike Miriam, chooses to paint only those scenes that correspond to her moral "ideals" of purity and godliness, thus appreciating the landscape of Rome from her tower at "a height of some fifty feet above the roofs of Rome" and totally ignoring the ugly and decaying parts of the city (Hawthorne 1974, p. 54).

Miriam's art is multifaceted; commonplace harmonious scenes are placed next to paintings of vindictive biblical heroines. A number of her drawings portray

domestic and common scenes, so finely and subtly idealized that they seemed such as we see at any moment, and everywhere; while still there was the identifiable something added, or taken away, which makes all the difference between sordid life and an earthly paradise (Hawthorne 1974, p. 45).

Reality and imagination are brought together; Miriam depicts Nature as an artist who is capable of adding her personal touch, her gentleness and finesse. 
Unlike Hilda, who deliberately distances herself from everything "sordid," Miriam's artistic talent lies in her ability to join the "sordid" with "paradise," thus producing works of art that arrest the attention of the viewer thanks to their simplicity and ingenuity. The domestic scene of "the lover winning the soft and pure avowal of bashful attention from the maiden" and her "drawing of an infant's shoe, half-worn out, with the airy print of the blessed foot within" cannot perhaps compete in their intricacy and technique with the paintings of the Old Masters, but the narrator seems to approve of these "so finely and idealized" scenes (Hawthorne 1974, p. 45). However, the presence of a sad woman with Miriam's features, continually peeping at a young pair of lovers from the outside without a chance of partaking in their cheerfulness, breaks the idyllic harmony:

There was one observable point, indeed, betokening that the artist relinquished, for her personal self, the happiness which she could so profoundly appreciate for others. In all those sketches of common life, and the affections that spiritualize it, a figure was portrayed apart, now it peeped between the branches of a shrubbery, amid which two lovers sat; now it was looking through a frosted window, from the outside, while a young wedded pair sat at their new fireside within...Always it was the same figure, and always depicted with an expression of deep sadness; and in every instance, slightly as they were brought out, the face and form had the traits of Miriam's own (Hawthorne 1974, p. 46).

Miriam's self-representation is conveyed by the narrator through his own gaze at the paintings and through Donatello's judgment of Miriam's art. The narrator is the one who comments on Miriam's idyllic pictures; Donatello becomes the narrator's mouthpiece whose task is to report on Miriam's brutal art. The narrator "plays it safe" - the harmony of Miriam's pleasant landscapes and her romantic depiction of lovers are certainly praised, reflecting Hawthorne's appreciation of tender and docile women and domestic bliss. There is even a sense of sympathy with the young artist who peeps at others' happiness from the outside "with an expression of deep sadness." She is doomed to be unfortunate; she cannot partake in the joy of the lovers.

Yet, the narrator's short applause of Miriam's art and his alleged compassion is quickly undermined by the overt criticism of the artist's portrayal of vengeful biblical women. Although Miriam is good at painting idyllic domestic scenes, her efforts are dedicated to the depiction of Jewish women, most of whom are murderesses. Interestingly, unlike the other characters in the romance, Miriam is described indirectly through a portrait of a woman who "seem[s] to be describing nine women out of ten in the person of my [Miriam's] lay-figure. For most purposes she has the advantage of the sisterhood" (Hawthorne 1974, pp. 41-42). Similar to the Jewish-American writer and poet, Rebekah Hyneman, who was Hawthorne's admirer and his contemporary, Miriam deeply appreciates female friendship. Hyneman calls it "a sweet communion" of women, thus suggesting that understanding and mutual compassion amongst women are of great value (Hyneman 1853, p. 107). We should not forget that Miriam's biblical namesake established a "female sisterhood." She was the Israelite women's leader, instructor and friend. Through art (using poetry, singing and dancing) she created a strong 
female alliance. When Miriam was sick with leprosy and isolated from the rest of the community, her female counterparts defended and supported her, refusing to continue their journey until their leader was back in camp.

Hawthorne's Miriam sees herself as part of a larger "sisterhood" of persecuted and victimized, but also strong, defiant and vengeful women who form a sort of kinship. She, like the lady in her painting, is "a woman with long dark hair, who threw up her arms with a wild gesture of tragic despair, and appeared to beckon him [Donatello] into the darkness along with her" (Hawthorne 1974, p. 41). The narrator, here takes a certain kind of "objective" stance, as if Miriam is the one who chooses her own depiction, though that description is given through the eyes of Donatello. Donatello, madly in love with his hostess, "was half startled at perceiving duskily" (Hawthorne 1974, p. 41) the image of the beautiful, but wild and despaired woman. The portrait of Miriam that summons the lover "into the darkness along with her" (Hawthorne 1974, p. 41) foreshadows Miriam and Donatello's future murderous association that results in the assassination of the Model, Miriam's persecutor. Here, it is the painting that pulls Donatello into the darkness: "When my eyes first fell upon her, I thought her arms moved, as if beckoning me to help her in some direful peril," says the lover (Hawthorne 1974, p. 42).

During the murder scene, Miriam's eyes entice Donatello to commit the crime. The narrator does not take the risk of being involved; he does not take a stance. Donatello, the innocent youth, is the speaker. The narrator "only" reports about the dread Donatello experiences when looking at Miriam's horrifying portraits. "As it chanced," he comments, "however, they [these paintings] gave the poor youth little delight" (Hawthorne 1974, p. 47). Some interesting questions should certainly be asked at this point: Why is the narrator reluctant to reveal his judgment on Miriam's paintings of Jewish women? Is it because their high artistic quality clashes with the dangerous message they carry? Is it because he is worried that by praising Miriam's art he might be accused of supporting belligerent feminist causes or spreading an anti-patriarchal agenda? These questions will probably remain unanswered.

The paintings Miriam consequently shows to Donatello are those of Jael, Judith and Salome. The narrator implies that she is fanatically obsessed with her merciless models: "over and over again, there was the idea of woman, acting the part of a revengeful mischief towards man" (Hawthorne 1974, p. 44). The narrator emphasizes Miriam's infatuation with her heroines and the sympathy she feels towards their causes. David Howard is right to maintain that "to talk of Miriam's art is really to talk of her character, and also in a way to talk of the artistic life which Hawthorne hints at but does not really come to" (Howard 1967, p. 125). Unlike Hilda's copies, Miriam's art exposes the "passionate and fiery conception of the subject in all earnestness," giving "the last touches in utter scorn" (Hawthorne 1974, p. 60). 


\section{Hawthorne's Ambivalence toward Miriam}

Hawthorne's narrator's ambivalent treatment of Miriam shows, on the one hand, his fascination with the audacity and zeal of her art, though, on the other, there seems to be a sense of holding back his praise when underscoring the ferocity of Miriam's Jewish models. He seems to be threatened by the "darker powers" and Eros of women in general, and those of the sensuous, defiant Jewish women, in particular. I suggest that Hawthorne would also have wanted to dare, on both literary and personal fronts, to passionately and fiercely conceive his fictional and imaginary subjects, but he fails to do so. It is not clear whether his hesitancy stems from his Puritan heritage, or from the "moral stance" he appropriated as a canonical American moralist.

What is apparent is Hawthorne's recurrent ambivalence towards any bold move or any socially questionable deed on the part of one of his female characters. Already in his earlier description of the Jewish woman whom he met at the Lord Mayor house in The English Notebooks, the sense of an inner struggle between the strong attraction and the repulsion, between his wish to build closer intimacy and his dread of impropriety (since the woman is Jewish), is evident. He writes that "I never should have thought of touching her, nor desired to touch her; for, whether owing to distinctness of race, my sense that she was a Jewess, or whatever else, I felt a sort of repugnance, simultaneously with my perception that she was an admirable creature" (Hawthorne 1941, p. 321). Is it only a racial aversion? Or, perhaps, this "sort of repugnance" refers to his inability to bridge the "accepted" norms, thus making it impossible to develop any sort of interaction with the beautiful Jewish lady? Or, possibly, such repugnance is a much broader one, ranging from his difficulty to fully support his other "dark" heroines, Hester Prynne in The Scarlet Letter, Beatrice in "Rapaccini's Daughter" (Hawthorne 1982, pp. 999-1005) and Zenobia in The Blithedale Romace, to his inability to break through the restrictive societal and artistic conventions.

Miriam, unlike her creator, is able, by means of her art, to form a close intimacy, a "sisterhood" with her models. Hawthorne's depicts Miriam as a "Wandering artist," without a family, a home or a homeland. Her art is her only possession, and the women she paints are her only associates except for Donatello. In the depiction of Miriam there are shades of a stereotype of the tragic "Wandering Jew," walking hopelessly from place to place. Art becomes an avenue through which her personal grief (the reasons for which are never clarified in the romance, though at times are hinted at) is united with the sufferings and the courageous acts of personal defense and national revenge that the Jewish women in her paintings represent. The narrator describes in detail the violent scenes of Sisera's murder by Jael and Holofernes's beheading by Judith:

The first that he [Donatello] took up was a very impressive sketch, in which the artist had jotted down her rough ideas for a picture of Jael driving the nail through the temples of Sisera. It was dashed off with remarkable power, and showed a touch or two that were actually lifelike and deathlike, as if Miriam had been standing by when Jael gave the first stroke of her murderous hammer, or as if she herself were Jael, and 
felt irresistibly impelled to make her bloody confession in this guise (Hawthorne 1974, p. 43).

As in all her other paintings, Miriam's metaphorical representations of the acts of murder are of importance. She almost becomes an active participant, which again hints at her sense of personal anguish and communion with the Jewish biblical heroines and foreshadows her own upcoming deed. However, the language the narrator uses here is one of manifest disapproval of Miriam; she is envisioned as a murderess who is about to give a "bloody confession" (but it is clear she will not) while the victim is helplessly lying at her feet, looking up at her. The narrator clearly disapproves of Miriam's art in the following passage:

Her first conception of the stern Jewess had evidently been that of perfect womanhood, a lovely form, and a high, heroic face of lofty beauty; but, dissatisfied either with her own work or the terrible story itself, Miriam had added a certain wayward quirk of her pencil, which at once converted the heroine into a vulgar murderess. It was evident that a Jael like this would be sure to search Sisera's pockets as soon as the breath was out his body (Hawthorne 1974, p. 43).

The narrator again challenges either Miriam's artistic ability or her integrity, this time putting the blame on Miriam herself. He implies that the artist rejects Jael's "terrible story," thus converting her heroine "into a vulgar murderess." The irony is that Miriam would not have painted Jael in the first place had she felt any resentment toward Jael's act. Moreover, by describing Jael as the most ignoble pickpocket, the narrator does not only undercut Jael's courageous act that symbolizes her determination and points at the fulfillment of God's will ("Blessed above women shall Jael the wife of Heber the Kenite be, blessed shall she be above women in the tent" [Judges 5: 24]), but insinuates at the widespread stereotype that views Jews as miserly money lenders or rogues.

Miriam's next painting is that of Judith, a pious Jewish widow who killed the King of Nineveh's general, Holofernes, who had been sent to subdue the Jews of Bethulia. Judith captivated Holofernes by her beauty, and eventually took advantage of the general's intoxication to cut off his head. The narrator again emphasizes the heroine's bloodthirstiness, never referring to her bravery or national heroism. The heroine is ironically compared to a cook who is about to boil the calf's head. Judith is compared to a vicious cook; Jael is compared to a thief. Miriam, their creator, is no less a criminal; her excessive passion and fiery makes her an extremely dangerous woman:

In another sketch she had attempted the story of Judith... Here, too, beginning with a passionate and fiery conception of the subject in all earnestness, she had given the last touches in utter scorn, as it were, of the feelings which at first took such powerful possession of her hand. The head of Holofernes... was screwing its eyes upward and twirling its features into a diabolical grin of triumphant malice, which it flung right in Judith's face. On her part, she had the startled aspect that might be conceived of a cook if a calf's head should sneer at her when about to be popped into the dinner-pot (Hawthorne 1974, pp. 43-44). 
Hawthorne's emotional ambivalence is apparent again, denoting to his ambiguity towards Jael and towards Miriam. He seemingly admires the "powerful possession" of Miriam's hand, her audacity and her daring. Miriam, similarly to her model, Judith, is a brave and earnest woman. Nevertheless, the audacity of the artist and that of her model is ironically undermined when this model is compared to a cook. The artist, one way or another, becomes Hawthorne's associate: both create powerful heroines. However, Hawthorne's narrator satirizes Miriam's creation, Judith, when describing her as a cook. The Jewish national heroine becomes a cook, killing a calf for dinner. Moreover, the narrator suggests that Miriam seems to totally identify herself with her Jewish model's criminal acts:

It was, indeed, very singular to see how the artist's imagination seemed to run on these stories of bloodshed, in which woman's hand was crimsoned by the stain; and how, too, - in one form or another, grotesque or sternly sad, - she failed not to bring out the moral, that woman must strike through her own heart to reach a human life, whatever were the motive that impelled her (Hawthorne 1974, p. 44).

It is possible that Hawthorne is critiquing himself and his own art indirectly here. Miriam's imagination allows her to "run on" stories, to be carried away to the remote past, and to draw from it her own story, her own unique creation, while Hawthorne, as an artist, seems to be impotent and unable to reach such levels of ingenuity. The narrator overtly accuses Miriam of identifying herself with the Jewish murderesses and of failing to portray the moral, feminine faculties a woman is said to possess. Miriam becomes an "unnatural" woman, a woman who resists her feminine inclinations and a woman who does not only defy patriarchal authority, but also violates accepted social norms that are necessary for the wellbeing of society. This view fits well with the stereotypical image of Jewish women discussed earlier in this article, portrayed as exceptionally sexually attractive, but at the same time, as unfeminine, defiant and emasculating.

The passage which summarizes Hawthorne's paradigm of a woman's proper behavior - a "woman must strike through her own heart to reach a human life" (Hawthorne 1974, p. 44) - when coupled with the narrator's description of the feminine ideal mentioned earlier in this article, unmistakably points to his poignant criticism of rebellious women. It also ironically alludes to the stereotypical depiction of the Jewish male, often portrayed in literature as passive and impotent. Unlike the male, the Jewish woman is brave, determined and self-reliant.

In addition to Miriam's identification and feeling of close kinship with her biblical Jewish models, her depiction of them is also equated with that of Beatrice $\mathrm{Cenci}^{1}$, another disobedient woman. Beatrice Cenci, an Italian noblewoman, was

\footnotetext{
${ }^{1}$ Beatrice Cenci (February 6, 1577-August 22, 1599) was an Italian noblewoman at the centre of a lurid murder trial in Rome. Beatrice was the daughter of Francesco Cenci, an aristocrat who, due to his violent temper and immoral behavior, had found himself in trouble with papal justice more than once. They lived in Rome in Palazzo Cenci, at the edge of Rome's Jewish ghetto. The legend is as follows: At home Francesco Cenci behaved as a brute. He abused his wife and his sons, and had reached the point of committing incest with Beatrice. He had been jailed for other crimes, but thanks to the leniency with which the nobles were treated, he had been freed early. Beatrice had tried to inform the authorities about the frequent mistreatments,
} 
involved in a scandalous murder of her father who committed incest with her. Hawthorne maintains that there is a definite physical resemblance between his character Miriam and the historical Beatrice. He also alludes that Beatrice's tragic fate is similar to that of Miriam; both are persecuted by a brutal male/father; both kill the fiend and both are harshly punished. Guido's famous picture of Beatrice, which Hilda so reverently copies, reminds us of Miriam's self-portrait:

The picture represented simply a female head; a very youthful, girlish, perfectly beautiful face, enveloped in white drapery, from beneath which strayed a lock or two of what seemed a rich, though hidden luxuriance of auburn hair. The eyes were large and brown, and met those of the spectator, but evidently with a strange, ineffectual effort to escape.... But, in fact, it was the very saddest picture ever painted or conceived; it involved an unfathomable depth of sorrow (Hawthorne 1974, p. 75).

The two women are youthful and beautiful but are also extremely distressed. Harvey L. Gable argues that by bringing up Beatrice's story, Hawthorne's intention was to emphasize Miriam's fallen morals: "Both unwittingly stirred the beast in a mad and maniacal suitor, rejected him, and caused him to fall into the chasm" (Gable 1998, p. 225). Hilda's view of Beatrice is not surprising. Ironically, although she harshly pronounces the victim guilty, saying that "her doom is just," she is at the same time fascinated by Beatrice's beauty and the possibility of meticulously copying Guido's portrait of his young model (Hawthorne 1974, p. 75). Indeed, I agree with Laurie Sterling's claim that Hilda's criticism of Beatrice foreshadows her future harshness toward Miriam, "just as Hilda passes judgment of Beatrice Cenci, so she will later pass judgment on Miriam" (Sterling 2000, p. 100). Moreover, I believe that in this scene, Hilda projects Hawthorne's intimidation of but at the same time his attraction to Beatrice's, and metaphorically, to Miriam's powerful and defiant character. Both Hawthorne and Hilda are captivated by the mystery that surrounds these "dark" women, but their enthrallment is constantly

but nothing had happened although everybody in Rome knew what kind of person her father was. When he found out that his daughter had reported against him, he sent Beatrice and Lucrezia away from Rome to live in the family's country castle. Exasperated, the four Cenci decided they had no alternative but to try and get rid of Francesco, and all together organized a plot. In 1598, during one of Francesco's stays at the castle, two vassals (one of whom had become Beatrice's secret lover) helped them to drug the man, stab him with a long nail through his eye and his throat, and hide the corpse. Somehow his absence was noticed, and the papal police tried to find out what had happened. Beatrice's lover was tortured, and died without revealing the truth. Meanwhile, the plot was discovered all the same and the four members of the Cenci family were arrested, found guilty, and sentenced to death. The common people of Rome, knowing the reasons for the murder, protested against the tribunal's decision and obtained a short postponement of the execution. But Pope Clement VIII showed no mercy at all: on September 11, 1599, at dawn, they were taken to Saint Angelo Bridge, where the scaffold was usually built. Giacomo was quartered with a mallet and had his limbs torn off and hung in the four corners; then Lucrezia and finally Beatrice took their turn on the block, to be beheaded with a sword. For the people of Rome Beatrice became a symbol of resistance against the arrogant aristocracy and a legend arose: every year on the night before her death, she came back to the bridge carrying her severed head (https://en.wikipedia.org/wiki/Beatri ce_Cenci) [Accessed 30January 2020]. 
subverted by social constraints. These "dark" women pose a threat to society's morals, and Hilda, the "dove-like" maiden, is unable to cope with decadence. Hawthorne, in a manner similar to his "daughter of Puritans" protagonist, is at once appalled and spellbound to his "dark" heroines.

Hawthorne contrasts Miriam's violent art with a very feminine occupation she is occasionally engaged in: needlework. When Donatello enters Miriam's studio, he finds her sewing. This peaceful domestic scene, soon discordantly undercut by the exhibition of Miriam's violent art, is in my opinion one of the most important passages in the novel, as it quite explicitly states the writer's views on the tasks "appropriate" for women and on the kind of artistic vocation - needlework women should do. The narrator goes into a lingering, at times even tiresome explanation of the gratification and accomplishments a woman might attain while at her needlework:

The artist was not just then at her easel, but was busied with the feminine task of mending a pair of gloves. There is something extremely pleasant, and even touching, at least, of very sweet, soft, and winning effect, in this peculiarity of needlework, distinguishing women from men. Our own sex is incapable of any such by-play aside from the main business of life; but women - be they of what earthly rank they may, however gifted with intellect or genius, or endowed with awful beauty have always some little handiwork ready to fill the tiny gap of every vacant moment. A needle is familiar to the fingers of them all. The slender thread of silk or cotton keeps them united with the small, familiar, gentle interests of life, the continually operating influences of which do so much for the health of the character, and carry off what would otherwise be a dangerous accumulation of morbid sensibility... Methinks it is a token of healthy and gentle characteristics, when women of high thoughts and accomplishments love to sew; especially as they are never more at home with their own hearts than while so occupied (Hawthorne 1974, pp. 39-40).

For Miriam, the communion with her own "kindred beings" (victimized women) is expressed through true feelings of sympathy and understanding of "the happiness which she could so profoundly appreciate for others" (Hawthorne 1974, p. 46). She does not need the needle to become an integral part of the feminine sisterhood; her "vast deal of human sympathy" (Hawthorne 1974, p. 46) does not stem from a common occupation (sewing) with other women, but from true compassion and kindness. The narrator's strong alarm about Miriam's nonfeminine peculiarity is expressed in the last sentence of his idyllic description of the woman while at needlework:

And when the work falls in a woman's lap, of its own accord, and the needle involuntarily ceases to fly, it is a sign of trouble, quite as trustworthy as the throb of the heart itself. This was what happened to Miriam (Hawthorne 1974, p. 40; italics mine).

Miriam, according to the narrator, by preferring to produce original art rather than preoccupying herself with needlework, actually destines herself to moral downfall. By defying "the healthy and gentle characteristics" of women's handiwork and preferring not to become a worshiper of the Old Masters, Miriam 
brings about her own ruin. The narrator suggests that there is no place for an original woman artist within the nineteenth-century conservative society. The moment a woman's needle "ceases to fly" it is irrevocably "a sign of trouble." Miriam is "punished" for breaking the social taboos, for daring and for the unwillingness to compromise her art.

Arnold Goldman, for example, suggests that for Hawthorne, Miriam is a dangerous person who might be suspected of "plotting to overthrow the Papal Government" (Goldman 1984, p. 385), and is therefore carefully watched by the Roman authorities. Such a suggestion is in line with Hawthorne's distaste of strong, political women, but it disregards the individual causes Miriam is fighting for, those of personal and artistic freedom. ${ }^{2}$ It is true that the Catholic Church, and the Model, disguised as a monk, represent the corruptive power of one religion trying to subdue another; yet Miriam's personal cause is not less important. I will argue in the next section of this article that the Model's character might be traced to Jewish origins, and, hence, if the Model is depicted as a Jew, Miriam is neither striving against the Church nor against Roman authorities, but against her ancestral traditions. Moreover, we should not forget that Miriam's choice of her tormentor, the Model, to be the one to pose for her work of art, makes him in a sense the original of this work. Metaphorically, by killing the Model Miriam is killing her art. Though Miriam tries to defy patriarchal dominance when practicing original art, ironically, the death of her male Model threatens her artistic career.

Instead of reading Miriam's defiance as a political act, I suggest that the feminist and artistic causes she is fighting for have not received the critical attention they rightfully deserve. "Miriam's noncompliance with the socially accepted norms which encourage women's meekness and subordination, her full physical and financial reliance on herself and the threat her personal conduct and artistic achievements pose to male artists such as Kenyon have never been seriously investigated" (Rabinovich 2012, p. 58). I maintain that Miriam's character and her art serve as an antithesis to Hawthorne's own artistic and personal aspirations. As a Jewish woman, a female artist and a foreigner, Hawthorne's figure of Miriam is the ultimate "Other"; actually, she is a triple other. As such, Miriam has the leeway and the audacity to break artistic and societal conventions, which I would speculate that Hawthorne would like to, but cannot, as a canonical writer, a distinguished diplomat and a family man, break. Hence, we note his constant, inexorable fascination with Miriam, but also his meticulous caution as he guards himself from being carried too far away by his dreams.

Miriam's noncompliance with the socially accepted norms, her refusal to remain within the conventional female spheres and the threat she poses to such male artists as Kenyon, who is equally threatened by the power his statue of Cleopatra has over him, remembering, as mentioned, that critics consider Kenyon

\footnotetext{
${ }^{2}$ Augustus M. Kolish maintains that "in her art, Miriam offers overt signs of a suppressed, Jewish identity that remains in spite of Catholic conversion" (Kolish 2001, p. 435). Kolish, who reads The Marble Faun in context of Edgardo Mortara's forced conversion, judges Miriam's noncompliant art as a tool of rebellion against the Catholic hegemony and their scheme of converting Italian Jews. He fails, however, to perceive Miriam's art in terms of her inner struggle and her private confrontation with male patriarchal oppression.
} 
Hawthorne's mouth-piece. In his biographical sketch of Anne Hutchinson ${ }^{3}$, Hawthorne contends that:

women's intellect should never give the tone of that of man... and woman, when she feels the impulse of genius like a command of Heaven within her, should be aware that she is relinquishing a part of the loveliness of her sex, and obey the inward voice with sorrowing reluctance, like the Arabian maid who bewailed the gist of prophecy (Hawthorne 1883, p. 217).

Hawthorne's ambiguity towards strong women such as Anne Hutchinson and towards the "dark women" of his own creation develops into an even more unconcealed resistance and condemnation when a bold Jewish woman is at stake. Hester, in a similar way to Miriam, violates the accepted norms and thus poses a threat to the social equilibrium and to patriarchal authority, but as an artist of the needle, Hester is depicted as still more "natural" and more feminine than Miriam. Miriam's rebellion is further complicated in Hawthorne's eyes. Hers is not only a revolt against male domination and the corruptive power of the Church, and it is neither just a personal struggle against a diabolic persecutor from the past who constantly haunts Miriam's steps. It is the revolt of an independently-minded artist who dares to confront the rigid moral and artistic norms set by the conservative, male-dominated elite. Nevertheless, though Hawthorne seems to underestimate independent and genuine female art and intellect, he dedicates much more attention and space to Miriam's bold art than to Hilda's practices as a copyist. The question is, why? If Miriam's art is immoral, defiant and anti-social, why does Hawthorne give such an extensive notice to every little detail in Miriam's paintings?

While rejecting Miriam's art as immoral, Hawthorne appropriates a condescending approach towards it and implies a moral lesson in his criticism. He tries to teach other women by scrutinizing Miriam's integrity. Such an attitude is well-summarized by his final remark with regards to Miriam's portrait of the Jewish Salome beheading John the Baptist. Salome, claims the narrator, was so terribly shocked by the saint's face, that "the look of gentle and heavenly reproach, with sad and blessed eyes fixed upward at the maiden," that "by the force of which [his] miraculous glance, her whole womanhood was at once awakened to love and endless remorse" (Hawthorne 1974, p. 44). This rendition of Salome's moral lesson relies heavily upon physical sensation, and denotes a type of learning expressed through physicality.

In fact, body language and sight play a significant role in the romance. While following John the Baptist's reproach expressed by his sad eyes Salome deeply

\footnotetext{
${ }^{3}$ Anne Hutchinson (July, 1591 - July, 1643) was the unauthorized Puritan preacher of a dissident church discussion group and a pioneer settler in Massachusetts, Rhode Island and New Netherlands. Anne held Bible study meetings for women, but because of how popular they were men soon came too, and she went beyond scriptural study to bold declarations of her own religious philosophy. Controversy ensued, and she was eventually banished from her colony. She is a key figure in the study of the development of religious freedom in Britain's American colonies (https://www.geni.com/people/Anne-Hutchinson/ 6000000005751454048) [Accessed 26 December 2019].
} 
regrets her crime. Similarly, Hawthorne implies that Miriam is a criminal who killed the Model with one glance: "There was short time to weigh the matter [throwing the Model from the cliff]; but he had his trial in that breath or two while I held him over the cliff, and his sentence in that one glance, when your eyes responded to mine!", says Donatello ( $M F$ 172; italics mine). Jonathan Auerbach insightfully comments that "throughout The Marble Faun, sight is an activity analogous to language: just as Kenyon executes Cleopatra 'with a word', so does Miriam execute her Model with a glance" (Auerbach 1980, p. 115).

\section{Conclusion}

Hawthorne's ambivalence towards strong women of his own creation, such as Hester, Beatrice and Zenobia, develops into a condemnation when a bold Jewish heroine is at issue. Although Hester, like Miriam, violates the norms and thus poses a threat to the societal equilibrium always carefully cherished by Hawthorne, Hester is much less dangerous than Miriam. An artist of the needle, Hester is safely within the conventional female sphere. Her creator, though disapproving of her act of adultery, remains supportive of the art she practices.

Miriam's rebellion is much more multifaceted, and therefore more dangerous. It is directed not only against the patriarchal domination, the threat that the Catholic Church and the Italian authorities pose; it is not only a personal struggle against a diabolic persecutor from the past. Although Miriam is portrayed as a courageous artist who is not afraid of painting strong, self-reliant heroines in her own way, her artistic and personal freedom is undermined by her vengeful obsession. Such art puts her in danger, especially if we consider Hawthorne's repeated allusions to the possibility that Miriam is constantly followed and watched, though he never makes it explicit who is persecuting the artist. Does her art somehow endanger the Roman authorities or her mysterious associates? Or, perhaps her art is too risky, as it encourages women to challenge the Church's and society's patriarchal values? Maybe it is what entices the Model to follow her? We are never provided with an answer. Yet it is suspect that Miriam never shows her work to her fellow artists except for Donatello, whom she trusts beyond a doubt. Probably the fear of being exposed accounts for her use of a pseudonym - Miriam Schaefer. On the other hand, I believe that Miriam's art, in spite of the dangers it may represent, is also beneficial. Her total identification with her artistic subjects and the choice of themes for her paintings both correspond to her feelings of gloom and empower her. Miriam's isolation from the artistic community of Rome and her resultant loneliness would be unbearable without the communion of "sisterhood" which, though only virtual, her Jewish models offer. 


\section{References}

Auerbach J (1980) Executing the model: painting, sculpture and romance-writing in Hawthorne's The Marble Faun. ELH 47(1): 103-120.

Bercovitch S (1988) The a-politics of ambiguity in the Scarlet letter. New Literary History 19(3): 629-654.

Brodtkorb P Jr. (1962) Art allegory in The Marble Faun. PMLA 77(3): 254-267.

Gable HL Jr. (1998) Liquid fire: transcendental mysticism in the romances of Nathaniel Hawthorne. Volume 2. New York: Peter Lang.

Glazener N (1997) Reading for realism: the history of a literary institution, 1850-1910. Durham: Duke UP.

Goldman A (1984) The plot of Hawthorne's The Marble Faun. Journal of American Studies 18(3): 383-404.

Hawthorne N (1883) Mrs. Hutchinson. In Bibliographical Sketches of Nathaniel Hawthorne. Boston: Houghton Mifflin.

Hawthorne N (1941) The English notebooks. Edited by Randall Stewart. New York: Modern Language Association.

Hawthorne N (1974) The Marble Faun; or, The Romance of Monte Beni. In Roy Harvey Pearce et al. (eds.), Volume 4 of The Centenary Edition of the Works of Nathaniel Hawthorne. Columbus: Ohio State UP.

Hawthorne N (1982) Rappaccini's daughter. In Tales and Sketches. New York: Literary Classics.

Howard D (1967) The fortunate fall and Hawthorne's The Marble Faun. In Ian Fletcher (ed.), Romantic Mythologies, 97-136. London: Routledge \& Kegan Paul.

Hyneman R (1853) The Leper and other poems. Philadelphia: A. Hart.

Kemp MA (1997) The Marble Faun and American postcolonial ambivalence. Modern Fiction Studies 43(1): 209-236.

Kolich AM (2001) Miriam and the conversion of the Jews in Nathaniel Hawthorne's The Marble Faun. Studies in the Novel 33(4): 430-443.

Levy LB (1970) The Marble Faun: Hawthorne's landscape of the fall. American Literature 42(2): 139-156.

Rabinovich I (2012) Re-dressing Miriam: $19^{\text {th }}$ century artistic Jewish women. New York: Xlibris.

Sterling LA (2000) A frail structure of our own rearing: the value(s) of home in The Marble Faun. American Transcendental Quarterly 14(2): 93-113. 